\title{
Company Performance Measurement Concepts Balance Scorecard (BSC)
}

\author{
Agus Jati Wiyono Niken Sulistyowati \\ Master of Management, University of Mercu Buana, Indonesia
}

\begin{abstract}
This study aims to measure Company Performance with the concept of Balance Scorecard (Case Study of PT Hutama Karya Infrastruktur). The type of sampling chosen in this study is with unlimited subjects. The results showed that (1) IPRs have increased financial performance since the transformation from 2016 to 2018 in terms of profitability, namely the Return on Assets (ROA) and Return on Equity (ROE) ratio, based on the customer's perspective, it is known that customers are satisfied with IPR performance, based on the internal business perspective, is known that IPR has formulated various company policies, especially in terms of production and finance, from the perspective of learning and growth, it is known that employees are satisfied with the policies made by IPR and (2) based on the results of the SWOT analysis, it is known that PT Hutama Karya Infrastruktur needs to establish an aggressive business development strategy through business diversification, both horizontally and vertically, while still maximizing the business potential that has been carried out now.
\end{abstract}

Keywords: Company Performance, SWOT Analysis, Customer Satisfaction, Balance Scorecard

DOI: $10.7176 / \mathrm{EJBM} / 12-24-03$

Publication date:August $31^{\text {st }} 2020$

\section{Introduction}

Research Background

Construction is a very important economic sector for the Indonesian economy, especially as a significant contributor to Gross Domestic Product (GDP). that various government infrastructure projects are reflected in the size of the government spending on the Infrastructure sector which continues to increase each year to reach $123.4 \%$ in 2017.

One of the companies in the construction sector that utilizes infrastructure development and transforms business is PT Hutama Karya (Persero). In carrying out its business activities, PT Hutama Karya (Persero) has 3 subsidiary companies. The subsidiary whose duty is to succeed the government's mandate to build the Trans Sumatra Toll Road is PT Hutama Karya Infrastruktur (PT. HKI), established on May 15, 2015, PT. HKI has the scope of business as implementing infrastructure construction.

The measurement of company performance aims to determine the extent to which the company's development has been achieved. Knowledge of current conditions is the basis for the company to make improvements and take steps to be taken at a later stage.

Business strategies should also integrate various functional activities to achieve company goals (Sutawidjaya and Rosalendro, 2016: 23). Furthermore, according to Masyhudzulhak (2016: 40) the performance measurement system is part of the strategy management process that shows a way how strategy planners set goals and draw strategy conclusions.

Balance Scorecard (BSC) which is a measurement concept derived directly from the company's business strategy needs to be continuously monitored, because it will direct employees towards the key success factors to build company success. To achieve this success the company must be motivated to make continuous improvements both to the performance measurement results and the performance benchmarks themselves.

In addition to the BSC, to formulate a business strategy that is able to analyze the company's internal and external circumstances, a SWOT analysis approach can be carried out. SWOT analysis is an analysis of the strengths, weaknesses, opportunities and threats that companies have and face. This makes the company must set a strategy to win the competition or at least to survive in the market.

\section{Formulation of the Problem}

Based on the identification of the problem and background of the problem described earlier, the researcher formulated the problem in this study.

1. How to evaluate the Strengths, Weakness, Opportunities, and Threats (SWOT) of PT Hutama Karya Infrastruktur

2. How is the performance of PT Hutama Karya Infrastruktur in all four perspectives of the Balanced Scorecard?

\section{Research purposes}

The purpose of this study is to determine whether there is an influence:

1. To find out and analyze the evaluation of Strengths, Weakness, Opportunities, and Threats (SWOT) of PT 
Hutama Karya Infrastruktur

2. To find out and analyze the performance of PT. Hutama Karya Infrastruktur in the four perspectives of the Balanced Scorecard

\section{Theoritical Review}

\section{Research Background}

Construction is a very important economic sector for the Indonesian economy, especially as a significant contributor to Gross Domestic Product (GDP). that various government infrastructure projects are reflected in the size of the government spending on the Infrastructure sector which continues to increase each year to reach $123.4 \%$ in 2017.

One of the companies in the construction sector that utilizes infrastructure development and transforms business is PT Hutama Karya (Persero). In carrying out its business activities, PT Hutama Karya (Persero) has 3 subsidiary companies. The subsidiary whose duty is to succeed the government's mandate to build the Trans Sumatra Toll Road is PT Hutama Karya Infrastruktur (PT. HKI), established on May 15, 2015, PT. HKI has the scope of business as implementing infrastructure construction.

The measurement of company performance aims to determine the extent to which the company's development has been achieved. Knowledge of current conditions is the basis for the company to make improvements and take steps to be taken at a later stage.

Business strategies should also integrate various functional activities to achieve company goals (Sutawidjaya and Rosalendro, 2016: 23). Furthermore, according to Masyhudzulhak (2016: 40) the performance measurement system is part of the strategy management process that shows a way how strategy planners set goals and draw strategy conclusions.

Balance Scorecard (BSC) which is a measurement concept derived directly from the company's business strategy needs to be continuously monitored, because it will direct employees towards the key success factors to build company success. To achieve this success the company must be motivated to make continuous improvements both to the performance measurement results and the performance benchmarks themselves.

In addition to the BSC, to formulate a business strategy that is able to analyze the company's internal and external circumstances, a SWOT analysis approach can be carried out. SWOT analysis is an analysis of the strengths, weaknesses, opportunities and threats that companies have and face. This makes the company must set a strategy to win the competition or at least to survive in the market.

\section{Formulation of the Problem}

Based on the identification of the problem and background of the problem described earlier, the researcher formulated the problem in this study.

1. How to evaluate the Strengths, Weakness, Opportunities, and Threats (SWOT) of PT Hutama Karya Infrastruktur

2. How is the performance of PT Hutama Karya Infrastruktur in all four perspectives of the Balanced Scorecard?

\section{Research purposes}

The purpose of this study is to determine whether there is an influence:

1. To find out and analyze the evaluation of Strengths, Weakness, Opportunities, and Threats (SWOT) of PT Hutama Karya Infrastruktur

2. To find out and analyze the performance of PT. Hutama Karya Infrastruktur in the four perspectives of the Balanced Scorecard 


\section{Framework}

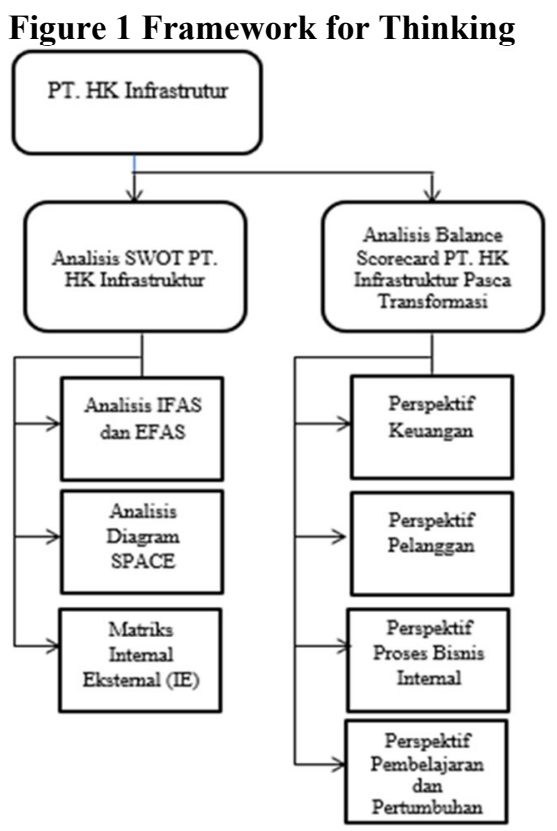

\section{Methodology}

\section{Research Methods}

According to Rangkuti (2013: 124) this perspective aims to find out how to make improvements and improvements. The fourth perspective in the Balanced Scorecard develops measurements and goals to encourage organizations to work and grow. The purpose of learning and growth perspectives is to provide infrastructure to support the achievement of the three previous perspectives. Financial perspectives, customers, and targets of internal business processes can reveal the gap between the existing capabilities of people, systems and procedures with what is needed to achieve a reliable performance.

In more detail, Garrison, et. al (2011:450) developed a map strategy regarding the perspective of the balanced scorecard in relation to the transformation of its application from strategy to performance measurement methods. The main idea through the integration of the four perspectives (which are linked using the vertical arrow direction) aims to learn the importance of improving internal business processes, in improving internal business processes it is necessary to improve customer satisfaction, and to improve customer satisfaction is important to improve the company's financial performance.

\section{Types of Research}

This type of research is descriptive.

\section{Population and Sample}

The sampling process is a very important process.

As for the deployment of samples performed on the entire bag i 's on the structure of the company are:

a. All Department Heads and Project Heads at PT Hutama Karya Infrastruktur

b. Se big part Project Leader and subordinates in PT Hutama Karya (Persero) related to the project of PT Hutama

Karya Infrastruktur (HKI)

c. Most of the staff are employees at the Head Office and at the PT Hutama Karya Infrastruktur.

\section{Method of Collecting Data}

The data collection techniques in use in this research is divided into two (2) groups according to the type of research data. Primary data sources used in this study used questionnaires and interviews. While secondary data sources used in this study include books, journals, articles, internet, reference books, and other sources related to research.

\section{Data Analysis Method}

Data analysis has the objective to convey and limit the findings to orderly and structured data that is more meaningful. Data analysis performed was a quantitative analysis revealed by numbers and calculations using Microsoft Excel. 


\section{Result and Discussion}

\section{Performance Measurement Based on Balance Scorecard}

Based on the results of the study note that PT Hutama Karya Infrastruktur have improved financial performance since transformed the year 2016 to 2018 in terms of profitability is the ratio of Return on Assets (ROA) and Return on Equity (ROE). The increasing profitability ratio, shows that PT Hutama Karya Infrastruktur has been able to manage all its assets to generate profits. However, if seen from the activity it is known that the growth in the ratio of Total Assets Turnover (TATO) of PT Hutama Karya Infrastruktur decreased in year 2018. The ratio of Total Asset Turnover (TATO) or asset turnover indicates that the company is able to leverage its assets well to generate high sales. Therefore, the ratio of Total Asset Turnover (TATO) which touches the negative number in terms of its growth shows that PT Hutama Karya Infrastruktur have not been able to leverage its assets to generate sales or revenues.

Furthermore, based on the customer's perspective, it is known that the customer is satisfied with the performance of PT Hutama Karya Infrastruktur. PT Hutama Karya Infrastruktur responded "Very Satisfactory" on the Company's performance with a score of 84. Even so, there are some indicators that still need to be improved such as Team Performance (Quite Satisfactory), Equipment (Quite Satisfactory) and OHS Implementation (Quite Satisfactory)

From an internal business perspective, it is known that PT Hutama Karya Infrastruktur has formulated various policies of the company, especially in terms of production and finance. In terms of production, PT Hutama Karya Infrastruktur (and HK group) has experience working on various categories of civil infrastructure, but only excels in the category of road and bridge construction services. In terms of material costs, the portion of the costs incurred by PT Hutama Karya Infrastruktur reached $31.88 \%$ or under the percentage of Companies benchmark of $32.51 \%$. Similarly, the portion of the cost elements in addition to the material, namely: wages, equipment and other costs, the portion of these costs in the cost structure of PT Hutama Karya Infrastruktur under the portion of the company's cost benchmark.

From the perspective of learning and growth, it is known that employees are satisfied with the policies implemented by PT Hutama Karya Infrastruktur. This is reflected in the employee satisfaction survey conducted. This is related to the transformation carried out by PT Hutama Karya Infrastruktur where the approach in the development of Sumber Daya Manusia based on the perspective of Human Capital Management (HCM) is no longer based Human Resource Management (HRM).

\section{SWOT Analysis of PT Hutama Karya Infrastruktur}

Based on the results of the SWOT analysis, it is known that the PT Hutama Karya Infrastruktur necessary to establish an aggressive business development strategy through diversification, both horizontally and vertically, while maximizing the potential of existing businesses are run today. As stated in the Company's longterm plan (RJPP). PT Hutama Karya Infrastruktur year 2018-2022, it is known that to realize the company's strategic position in the industry with the company's internal strengthening and improving the competitiveness of companies and targets operating revenue of 14.7 trillion rupiah in 2022.

PT Hutama Karya Infrastruktur has several options of corporate strategy, ie, vertical integration (forward and backward integration) and horizontal integration (diversification of infrastructure category). In the next 5 years, PT Hutama Karya Infrastruktur chose not to carry out forward integration efforts, which is to become an investment company in infrastructure for the next 5 years. This is caused by several factors, namely the business focus of PT Hutama Karya Infrastruktur within the framework of the campaign for the construction of the Trans Sumatra Highway (JTTS) and to avoid the risk of overlapping scope of business with the parent company (PT Hutama Karya).

In terms of efforts to provide material and subcontractor, PT Hutama Karya Infrastruktur has the option to do a backward integration, namely soil improvement work, earthworks, supply of ready mix concrete, aggregates, precast concrete, iron bones and hot mix asphalt. PT Hutama Karya Infrastruktur chose to do backward integration of soil improvement subcontractor work into self-managed or in-house work. This is done because the soil improvement work has quite high profit margins, so there is potential to increase the profit margins that can be obtained by PT Hutama Karya Infrastruktur.

\section{Conclusion}

Based on the results of the research in the previous chapter, the following conclusions are generated in this study. Based on research results, it is known that based on financial perspective it is known that PT Hutama karya Infrastruktur have improved financial performance since transformed the year 2016 to 2018 in terms of profitability is the ratio of Return on Assets (ROA) and Return on Equity (ROE). Based on the customer's perspective, it is known that the customer has been satisfied with the performance of PT Hutama Karya Infrastruktur . From an internal business perspective, it is known that PT Hutama Karya Infrastruktur has formulated various policies of the company, especially in terms of production and finance. Finally, from the perspective of learning and growth, 
it is known that employees are satisfied with the policies implemented by PT Hutama Karya Infrastruktur .

Based on the results of the SWOT analysis, it is known that the PT Hutama Karya Infrastruktur necessary to establish an aggressive business development strategy through diversification, both horizontally and vertically, while maximizing the potential of existing businesses are run today.

\section{Suggestion}

Based on the conclusions above, the following are the suggestions raised in this study.

Suggested PT Hutama Karya Infrastruktur increase the ratio of the activity. PT Hutama Karya Infrastruktur required to enhance the company's ability to manage all the assets held in its marketing policy. With an improved activity ratio, all funds embedded in the company's assets can be used for investment in other assets that are more productive so that the company's profitability can continue to increase.

Suggested PT Hutama Karya Infrastruktur improve strategies Sumber Daya Manusia through the launch of a training program and the Management Development Program (MDP) that gave birth to those employees who are more qualified and knowledgeable so that they can improve corporate performance through innovations made.

It is recommended in further research, to compare with other companies to find out the Indonesian construction market benchmark. This will be a benchmark for PT Hutama Karya Infrastruktur to formulate the company's future strategy.

\section{References}

Alma, Buchari. 2011. Manajemen Pemasaran dan Pemasaran Jasa. Bandung: CV. Alfabeta.

Garrison, Ray. 2013. Akuntansi Manajerial. Jakarta: Salemba Empat.

Ghozali, Imam, Hengky Latan. 2015. Konsep, Teknik, Aplikasi Menggunakan Smart PLS 3.0 Untuk Penelitian Empiris. Semarang: BP Undip.

Grewal and Levy. 2008. Marketing. New York: Mc.Graw Hill

Luis, S. 2010. Step by Step in Cascading Balance Scorecard to Functional Scorecard. Jakarta: Gramedia Pustaka Utama.

Masyhudzulhak, H. 2016. Manajemen Strategi. Bengkulu: Lembaga Pengkajian dan Pengembangan Sumberdaya. Muchtar, H. 2010. "Penerapan Penilaian Autentik dalam Upaya Peningkatan Mutu Pendidikan". Jurnal Pendidikan Penabur. Vol. 14.

Rangkuti, Freddy. 2011. Analisis SWOT Teknik Membedah Kasus Bisnis. Jakarta: Gramedia.

Rangkuti, Freddy. 2013. Teknik Membedah Kasus Bisnis Analisis SWOT Cara Perhitungan Bobot, Rating, dan OCAI. Jakarta: Penerbit PT. Gramedia Pustaka Utama.

Sutawidjaya, Achmad H dan Rosalendro Eddy Nugroho. 2016. Strategi Operasi \& Proses Manajemen. Bengkulu: Lembaga Pengkajian dan Pengembangan Sumberdaya. 